\title{
Genetics of common bean resistance to white mold
}

Flávia Fernandes Carneiro ${ }^{1}$ *, João Bosco dos $\operatorname{Santos}^{1}$, Paulo Roberto Carvalho Gonçalves ${ }^{1}$, Rafaela Priscila Antonio ${ }^{2}$ and Thaís Paula de Souza ${ }^{3}$

Received 20 December 2009

Accepted 21 December 2010

\begin{abstract}
The objective of the research was to investigate the nature and magnitude of the genetic factors involved in the resistance of the common bean to white mold. The lines $G 122$ (resistant) and M20 (susceptible) were crossed to yield $F_{1}$ and $F_{2}$ generations and $F_{2: 3}$ progenies. The experiment was set up using the random block design with two replications, each of which was evaluated twice with fungal inoculations being performed on 28 and 38 day-old plants using the straw test method. Six to eight days after inoculation evaluations were conducted on individual plants and at the level of means of progenies using a diagrammatic scale ranging from 1 to 9. The additive-dominance model adopted was efficient, and the genetic control of resistance was predominantly due additive effects. Estimates of broad-sense heritability indicated that selection would be more efficient when based on the means of progenies and when successive inoculations are employed.
\end{abstract}

Key words: Sclerotinia sclerotiorum; Phaseolus vulgaris; genetic parameters.

\section{INTRODUCTION}

Sclerotinia sclerotiorum (Lib.) de Bary, the causal agent of white mold, is a soil borne necrotrophic fungus, and one of the most devastating diseases of the common bean (Phaseolus vulgaris L.). There are, however, a few reports concerning the genetic factors responsible for the resistance of the bean to this disease, and the results that have been obtained are controversial. According to Antonio et al. (2008) the character is controlled by a single gene. Genchev and Kiryakov (2002) reported monogenic dominant (in the field) and recessive (in the greenhouse) on the control for white mold resistance in the dry bean breeding line A 195. Abawi et al. (1978) and Schwartz et al. (2006) also reported a single dominant gene controlling resistance to white mold in different inter-specific $P$. vulgaris/P. coccineus populations. In contrast to single inheritance, more than ten quantitative trait loci (QTL) have been identified that influence resistance to white mold, mostly with small to moderate effects (Milkas et al. 2001, Park et al. 2001, Kolkman and Kelly 2003, Milkas et al. 2003, Ender and Kelly 2005). Resistance QTL have been located on all linkage groups (chromosome) except 9, 10 and 11 of the integrated common bean map (Kelly et al. 2003, Miklas et al. 2006). Since the results relating to gene expression depend on the type of genetic material studied in one plant species, it is injudicious to attempt to generalize for all plant species, especially when the genetic control involves many loci. Furthermore, when the influence of environmental factors is pronounced, it becomes more complex to acquire evidence concerning the underlying contribution of genetic factors for the character under consideration (Vencovsky and Barriga 1992).

The improvement of white mold resistance has been very slow because of the low heritability, the cumbersome screening methods due to the environmental influences and the use of inefficient breeding methods. Also, it is

\footnotetext{
${ }^{1}$ Universidade Federal de Lavras (UFLA), Departamento de Biologia, C.P. 3037, 37.200-000, Lavras, MG, Brazil. *E-mail: bioffc@yahoo.com.br

${ }^{2}$ Universidade Federal Rural do Semi-Árido, Departamento de Ciências Vegetais, C.P. 1373, 59.625-900, Mossoro, RN, Brazil

${ }^{3}$ Universidade de São Paulo, Escola Superior de Agricultura "Luiz de Queiróz”, Departamento de Genética, C.P. 83, 13.400-970, Piracicaba, SP, Brazil
} 
important to consider the architectural traits that help plants to avoid white mold (Fuller et al. 1984, Kolkman and Kelly 2002).

In the context of successful breeding programs, it is essential to identify amongst the various phenotypes those individuals that present not only a desirable genotype but also contain the maximum concentration of favorable alleles. Since most known sources of resistance are not adapted, it is necessary to clarify the genetic control of bean resistance to white mold through crossing that source with elite lines. The aim of the present study was to determine the nature and magnitude of the genetic factors involved in the resistance of the common bean to white mold.

\section{MATERIALS AND METHODS}

The experiments were conducted in a greenhouse located at the Biology Department of the Universidade Federal de Lavras (UFLA) in Lavras, Minas Gerais, Brazil. The Andean common bean line G122 was employed as a source of white mold-resistant. This line has large, fawn seeds with reddish spots and exhibits determinate growth (Kolkman and Kelly 2003, Chung et al. 2008). On the other hand, the line presents various characteristics that are agronomically disadvantageous including a lack of adaptation to the cultivation conditions of the State of Minas Gerais. Line M20 presents a carioca type bean, a type II growth habit and resistance to anthracnose (alleles Co- 42 , Co-5 and Co7) and to some races of the angular leaf spot agent: it is, however, highly susceptible to white mold. Crossing G122 $\left(\mathrm{P}_{1}\right)$ with $\mathrm{M} 20\left(\mathrm{P}_{2}\right)$ yielded generations $\mathrm{F}_{1}$ and $\mathrm{F}_{2}$ and $\mathrm{F}_{2: 3}$ progeny. In total, 20 plants of line G122, 20 of line M20, 20 of $F_{1}, 60$ of $F_{2}$ and 120 of $F_{2: 3}$ progenies were employed in one experiment.

The experiment was set up using a random block design with two replications. Individual plots comprised of 5 plastic pots ( $3.5 \mathrm{~L})$, each containing two plants. Each replication was organized according to the following structure: one plot for each of the parents, one plot for the $F_{1}$ generation, three plots for the $F_{2}$ generation, and one plot for each $\mathrm{F}_{2: 3}$ progeny. All plants were cultivated under standard conditions with regular irrigation for $5 \mathrm{~min}$ at intervals of $3 \mathrm{~h}$.

Sclerotia of S. sclerotiorum were collected from an experimental field located in Ijaci, State of Minas Gerais, Brazil and inoculated into Petri dishes containing potato dextrose agar (PDA) medium supplemented with chloramphenicol. The dishes were incubated under biological oxygen demand (BOD) conditions at $20 \pm 3^{\circ} \mathrm{C}$ for 3 days.
In order to obtain more uniform cultures, an inoculum of the fungal mycelia was subcultured and incubated as described above under a $12 \mathrm{~h}$ photoperiod.

The infection of plants with fungi was performed using the straw test method of Petzoldt and Dickson (1996), which involved making a cut in the main stem of the plant approximately $2.5 \mathrm{~cm}$ from the first node and introducing (with the help of a sterile Eppendorf tip) an agar disc containing subcultured mycelia. Each replication was evaluated twice as recommended by Terán and Singh (2008) by inoculating the mycelia into 28 and 38 day-old plants.

Bean plants were evaluated for white mold symptoms some 6 to 8 days after infection using a diagrammatic scale (ranging from 1 to 9) as follows: (1) no visible symptoms, (2) fungal growth beyond the inoculation point, (3) fungal growth near the first node, (4) fungal growth around the first node, (5) fungal growth beyond the first node, (6) fungal growth near the second node, (7) fungal growth around the second node, (8) fungal growth beyond the second node, and (9) death of the plant.

For the analysis at the individual plant level the $\mathrm{P}_{1}$, $\mathrm{P}_{2}, \mathrm{~F}_{1}$ and $\mathrm{F}_{2}$ were used using the following model: $\mathrm{Y}_{\mathrm{ijk}}=$ $\mathrm{m}+\mathrm{t}_{\mathrm{i}}+\mathrm{b}_{\mathrm{j}}+\mathrm{e}_{(\mathrm{ij})}+\mathrm{p}_{(\mathrm{k}) \mathrm{ij}}$ where: $\mathrm{Y}_{\mathrm{ijk}}$ : observed value of the $\mathrm{k}$ plant from i treatment in the $\mathrm{j}$ block; $\mathrm{m}$ : overall mean; $\mathrm{t}_{\mathrm{i}}$ : effect of the treatment $i=1$ to $4 ; b_{j}$ : effect of block $j=1$ to $2 ; \mathrm{e}_{(\mathrm{ij})}$ : experimental error; $\mathrm{p}_{(\mathrm{k}) \mathrm{ij}}$ : effect of $\mathrm{k}$ plant in the $\mathrm{j}$ block that received the treatment i.

For estimating the mean and variance components the least squares method was used, and the fit of the model was verified using the coefficient of determination $\mathrm{R}^{2}$ (Ramalho et al. 1993). For estimating the mean components the mean values of the parents were considered, $F_{1}, F_{2}$ and $\mathrm{F}_{3}$. For estimating the variance components the variances at plant level of the parents were used, $F_{1}, F_{2}$ and within $\mathrm{F}_{2: 3}$ progenies, and also the variance among the mean of the $F_{2: 3}$ progenies. The mean variance within $\mathrm{F}_{2: 3}$ were estimated from individual variance per plot. Since the numbers of plants in each plot were not constant, the mean variance estimation was performed according to Ramalho et al. (2005).

Analysis of variance (ANOVA) of the scores attained by each $\mathrm{F}_{2: 3}$ progeny were performed considering the age of the plants (28 and 38 days) at the first and second evaluation, respectively. The joint ANOVA was set up using the following model: $\mathrm{Y}_{\mathrm{ijq}}=\mathrm{m}+\mathrm{t}_{\mathrm{i}}+\mathrm{e}_{\mathrm{q}}+\mathrm{b}_{(\mathrm{q}) \mathrm{j}}+(\mathrm{te})_{\mathrm{ij}}+$ $e_{\mathrm{qij}}$ where: $\mathrm{Y}_{\mathrm{ijq}}$ : is the score of the $\mathrm{i}$ progeny, from the $\mathrm{j}$ block, within the q evaluation time; m: mean of all 
progenies; $\mathrm{t}_{\mathrm{i}}$ : effect of the i progeny $(\mathrm{i}=1,2,3, \ldots, 120)$; $\mathrm{e}_{\mathrm{q}}$ : effect of the q evaluation time $(\mathrm{q}=1,2) ; \mathrm{b}_{(\mathrm{q}) \mathrm{j}}$ : effect of the $j$ block within q evaluation time $(j=1,2)$; (te $)_{i q}$ : effect of the progenies $\mathrm{x}$ evaluation times interaction; $\mathrm{e}_{\mathrm{qij}}$ : mean experimental error.

Broad-sense $\left(\hat{h}_{a}^{2}\right)$ and strict-sense $\left(\hat{h}_{r}^{2}\right)$ heritabilities were estimated at the individual plant level, but only the former was calculated at the level of the mean of $\mathrm{F}_{2: 3}$ progenies (Ramalho et al. 1993). Confidence interval estimators for heritability were obtained from the expressions developed by Knapp et al. (1985), while the number of genes $(K)$ involved in the control of the trait was determined by the method of Wright (1934).

\section{RESULTS AND DISCUSSION}

In order to study the genetic control of a trait such as the response to white mold, it is essential that the reactions of the parents are statistically dissimilar $(\mathrm{P} \leq 0.01)$. In the present study, the scores attained by the G122 line were 3.00 and 4.61 in the first and second evaluations, respectively, whereas the M20 line gave values of 4.56 and 7.13, respectively, thus confirming the high susceptibility of the latter to white mold (Table 1). Miklas et al. (2001), who also applied the straw test, reported that G122 was moderately resistant with a score of 5.2, whereas Antonio et al. (2008) reported that G122 was highly resistant according to the oxalic acid method.

The difference between the scores obtained in evaluations conducted using 28 and 38 day-old plants can be explained in terms of different environmental conditions and, principally, by the age of the plants. In the first evaluation, the average performance of the progenies from each generation was similar to that of the parents, indicating that the trait was predominantly regulated by additive effects (Silva et al. 2008). However, in the second evaluation the means of these populations suggested the occurrence of dominance effects. The higher mean scores obtained with the parents in the second evaluation were probably caused by the inoculation having occurred during the period of inflorescence. The fungus attacks all parts of the plant mainly at the start of flower formation and during pollination of flowers, since the flowers serve as basic sources of nutrients to initiate infection by the spores (Huinter et al. 1978).

Estimates of the genetic parameters were based on the means of the generations and were obtained using a reduced model comprising the three parameters mean of the homozygotes $(m)$, additive deviation $(a)$ and dominant deviation $(d)$. The fit of the data to the additive-dominance model was highly satisfactory since $\mathrm{R}^{2}$ was approximately $100 \%$ and the observed means concurred with the expected mean values (Table 1 ).

In both evaluations, the additive genetic effects were more important, by a factor of two, in the determination of the trait than the dominance effects, a result that demonstrates the power of the additive effects in the expression of white mold resistance. However, the observed additive genetic effects were statistically significant only in the first evaluation, whereas in the second evaluation it was merely possible to observe a tendency. Thus, the study of the genetic control of white mold resistance was more effective in the first evaluation than in the second. The prevalence of additive effects on the genetic control of white mold resistance indicates that the identification of superior genotypes (with a high concentration of favorable alleles) is straightforward, an essential condition for the genetic improvement of the common bean. This result corroborates the findings of Antonio et al. (2008) who observed the predominance of additive effects in bean resistance to white mold by using the oxalic acid reaction. A similar predominance was also observed with respect to the control of lesions inflicted by S. sclerotiorum in aerial parts of sun flower and colza (Zhao et al. 2004).

In the present study, the mean degrees of dominance in the first and second evaluations were, respectively, estimated at -0.41 and 0.48 , values that indicate a partial dominance according to Ramalho et al. (1993). It is imperative, however, to emphasize the divergent values of $\hat{d}$ in the two evaluations. Owing to the large experimental error, it is not possible to establish any conclusions regarding such estimates or the parameters derived there from. Hence, it is safer to assume the occurrence of an additive effect in the control of white mold resistance.

It should be noted that the use of the components of the mean presents some limitations including the fact that the additive $(\hat{a})$ and dominance $(\hat{d})$ effects may counterbalance. Thus, some genotypes with several alleles may exhibit positive values, whilst others present negative values. As a result, the mean value of $\hat{a}$ may be very small or even $\leq 0$. Since the mean value of $\hat{d}$ corresponds to the sum of the effects of all heterozygote loci, its value can also be small or $\leq 0$, even when each gene individually shows complete dominance. This situation can be explained by the fact that when there is dominance in opposing directions the effects are mutually annulled (Ramalho et 
$\vec{D} \quad$ Table 1. Estimations of the components of the mean and degree of dominance relating to the response of common bean plants (obtained by crossing G122 x M20 lines) to white mold evaluated for individual plants 28 and 38 days after sowing

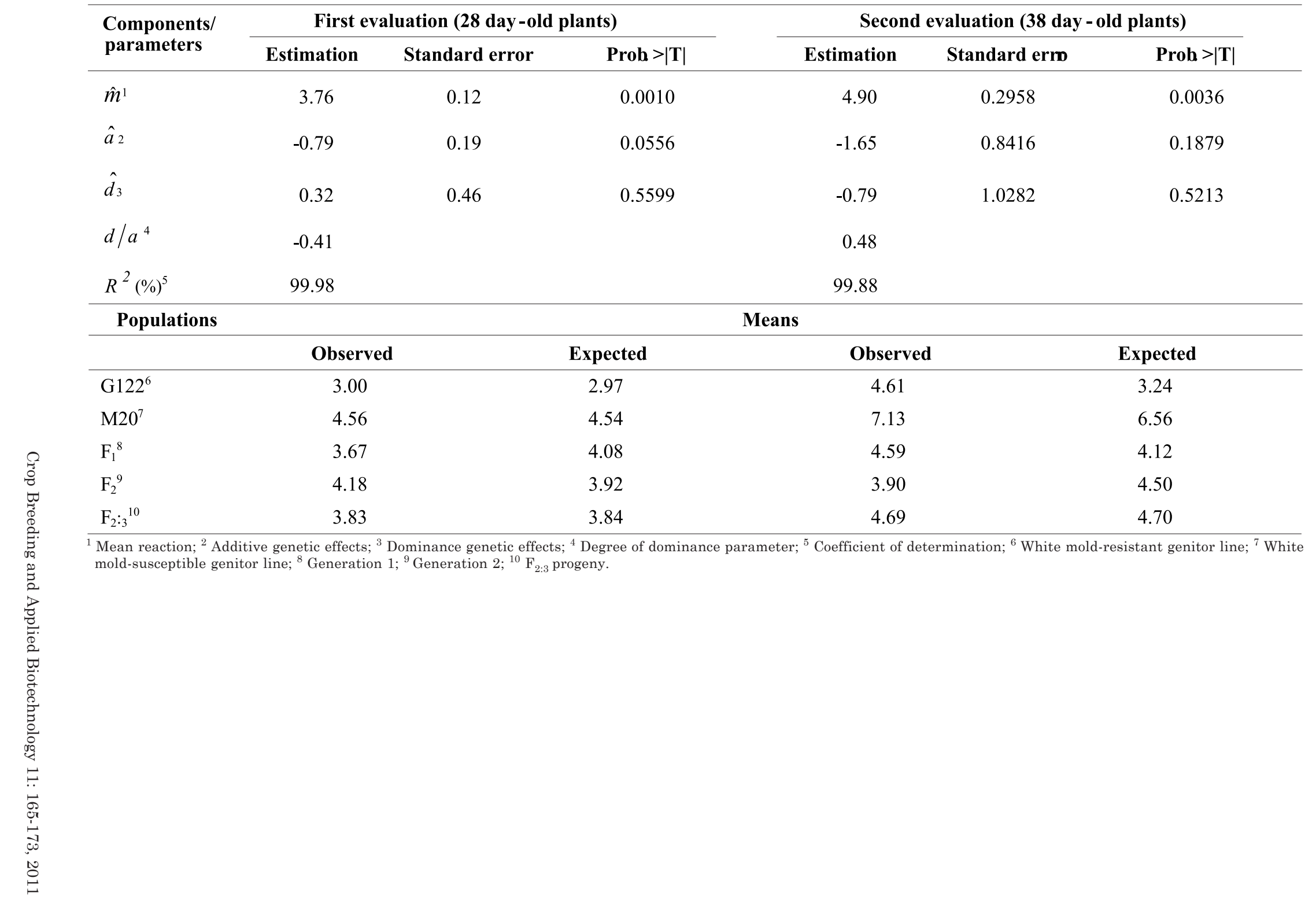


al. 1993). Note, however, that a negative $\hat{a}$ derives from the lowest scores that refer to resistant genotypes, hence the value represents the additive contribution of the allele for white mold resistance.

In consideration of the limitations of the components of the mean method, and the complexity of the information, it was necessary to carry out a combined study on the components of the means and variance in order to obtain more details about the phenomenon (Cruz et al. 2004). The components of variance proposed by the model included additive genetic variance $\left(\hat{\sigma}_{\mathrm{A}}^{2}\right)$, dominance genetic variance $\left(\hat{\sigma}_{D}^{2}\right)$ and environmental variance $\left(\hat{\sigma}_{e}^{2}\right)$. As shown in Table 2 , all data fitted with the considered model since $\mathrm{R}^{2}$ was equivalent to 93.57 and $92.63 \%$, respectively, for the first and second evaluations. Hence, it is possible to state that variance concerning resistance to white mold may be explained by the additive, dominance and environmental effects.

Similarly to the results obtained with the means, the additive variance was predominant in both evaluations. In the first evaluation the limits of the dominance variance included negative values, indicating that some individual values were equivalent to zero, whereas in the second evaluation the values suggest the occurrence of dominance variance. Regarding environmental variance, it was possible to detect that the environment exerted considerable influence on the expression of white mold resistance, as demonstrated by the values of $\hat{\sigma}_{e}^{2}$ in the first and second evaluations (1.9546 and 1.7451, respectively), which corresponded to 54.37 and $55.92 \%$, respectively, of the total variance (Table 2).

In the first evaluation, only strict-sense heritability $\left(\hat{h}_{r}^{2}=33 \%\right.$ ) was determined since the dominance variance was assumed to be equal to zero. In the second evaluation the values of broad-sense heritability $\left(\hat{h}_{a}^{2}\right)$ and were 44 and 31 $\%$, respectively. The larger value of $\hat{h}_{a}^{2}$ indicates that the influence of the dominance effect on the trait was less pronounced than the additive effect. Although the heritability values are relatively low, they are large enough to suggest that white mold resistance can be effectively selected using the straw test method.

The results of the present study indicate that one resistance gene is involved in the control of white mold, although the precise determination of the number of genes is almost impractical owing to the influence of the environment on the expression of the trait, and the small number of $F_{2}$ plants used for the evaluation per plant (Ramalho et al.
1993). In the present study we decided to use a higher number of $\mathrm{F}_{2}$ plants for generating the $\mathrm{F}_{2: 3}$ progenies which gave more reliable results in the estimates genetic and phenotypic parameters. Miklas et al. (2001) identified a single QTL with large effect (approximately $37 \%$ ) for the resistance trait against white mold. However, it is known that the genetic control of white mold in the field is quantitative and highly influenced by the environment (Castaño et al. 1993) and other contributing factors including the upright stature (Miklas et al. 2003). For these reasons, mycelial inoculation is considered to be the most efficient method for investigating the genetic control and selection of $S$. sclerotiorum-resistant cultivars (Terán and Singh 2008).

The mean reaction data evaluated for the $\mathrm{F}_{2: 3}$ progenies were submitted to individual and joint ANOVA (Tables 3 and 4). Individual ANOVA revealed a significant effect of the progenies $(\mathrm{P} \leq 0.01)$, indicating that the genitor lines of the segregating generations differed with respective disease resistance and that the progenies were genetically dissimilar regarding their levels of resistance. The variability among the mean reaction of the $\mathrm{F}_{2: 3}$ progenies is illustrated in Figure 1, and the scores varied from 1.45 to 7.50 .

In the $\mathrm{F}_{2: 3}$ progenies, $\hat{h}_{a}^{2}$ was $39 \%$ (confidence interval 13.05-57.77\%) in the first evaluation and $47 \%$ (confidence interval $24.36-63.26 \%$ ) in the second evaluation. Since the lower and upper limits of heritability were positive, the estimations are very reliable and success with selection could be guaranteed. In the second evaluation, the heritability value was slightly higher than in the first, hence the selection should be more efficient when inoculation with pathogen is performed using 38 day-old plants.

Considering that the heritability values $\left(h^{2}\right)$ calculated from the progeny means were similar to those obtained from individuals, it is likely that selection using the straw test would be equally efficient. However, selection based on the former would probably be more efficient since there were significant differences between the means of the $\mathrm{F}_{2: 3}$ progenies, and the $h^{2}$ values were more reliable.

Miklas et al. (2001) observed that the heritability of bean white mold resistance, as determined by the straw test method, was lower in the greenhouse $(0.65)$ than in the field (0.78). In this context, these authors demonstrated that the bean line A55, which exhibits erect and determinate growth, was susceptible to white mold when evaluated in the greenhouse but resistant when evaluated in the field. Such findings can be explained by physiological resistance (detected by the straw test) and escape mechanisms that 
Table 2. Estimations of the components of variance relating to the response of common bean plants (obtained by crossing G122 x M20 lines) to white mold evaluated for individual plants 28 and 38 days after sowing

\begin{tabular}{|c|c|c|c|c|c|c|c|c|c|c|}
\hline & \multicolumn{5}{|c|}{ First evaluation ( 28 day-old plants) } & \multicolumn{5}{|c|}{ Second evaluation (38 day-old plants) } \\
\hline & Estimation & Error & Lower limit & Upper limit & Prob. $>|\mathbf{T}|$ & Estimation & Error & Lower limit & Upper limit & Prob. $>|\mathbf{T}|$ \\
\hline$\hat{\sigma}_{\mathrm{A}}^{2^{1}}$ & 0.9685 & 0.4636 & 0.8077 & 1.1830 & 0.172 & 0.9781 & 1.3536 & 0.7472 & 1.3359 & 0.540 \\
\hline$\hat{\sigma}_{\mathrm{D}}^{2^{2}}$ & -0.6715 & 1.5092 & -0.5242 & -0.8914 & 0.699 & 0.3977 & 0.2997 & 0.3215 & 0.5048 & 0.316 \\
\hline$\hat{\sigma}_{\mathrm{e}}^{2^{3}}$ & 1.9546 & 0.7832 & 1.3396 & 3.1189 & 0.130 & 1.7451 & 0.7525 & 1.200 & 2.7684 & 0.146 \\
\hline $\mathrm{R}^{2}(\%)$ & 93.57 & & & & & 92.63 & & & & \\
\hline
\end{tabular}

${ }^{1}$ Additive genetic variance; ${ }^{2}$ Dominance genetic variance; ${ }^{3}$ Environmental variance. 
Table 3. Analysis of variance of progenies $F_{2: 3}$ considering the means of the plots obtained in two evaluations

\begin{tabular}{|c|c|c|c|}
\hline \multirow[b]{2}{*}{ Sources of variation } & \multirow[b]{2}{*}{ df } & \multicolumn{2}{|c|}{ Mean square } \\
\hline & & $\begin{array}{c}\text { First evaluation } \\
\text { (28 day-old plants) }\end{array}$ & $\begin{array}{l}\text { Second evaluation } \\
\text { (38 day-old plants) }\end{array}$ \\
\hline Repetition & 1 & 327.49 & 75.2 \\
\hline Progeny & 119 & $4.67 * *$ & $3.87 * *$ \\
\hline Error & 119 & 2.83 & 2.04 \\
\hline Within plot & & 1.36 & 1.32 \\
\hline Coefficient of variance $(\%)$ & & 22.79 & 14.53 \\
\hline \multirow[t]{2}{*}{ Mean } & & 3.77 & 4.69 \\
\hline & & \multicolumn{2}{|c|}{ Estimation of parameters } \\
\hline Phenotypic variance & & 2.33 & 1.93 \\
\hline Environmental variance & & 1.41 & 1.02 \\
\hline Genotypic variance & & 0.92 & 0.91 \\
\hline Broad-sense heritability & & $0.39(0.13-0.58)$ & $0.47(0.24-0.63)$ \\
\hline
\end{tabular}

** Statistically significant at $1 \%$ probability according to the $\mathrm{F}$ test.

Table 4. Joint analysis of the mean scores attained by $\mathrm{F}_{2: 3}$ progenies in two evaluations

\begin{tabular}{lcc}
\hline Source of variation & df & Mean square \\
\hline Evaluation & 1 & $149.77^{* *}$ \\
Progenies & 119 & $1.85^{* *}$ \\
Evaluation period $x$ progenies & 119 & 0.86 \\
Error & 238 & 2.435 \\
\hline Coefficient of variance $(\%)$ & & 15.05 \\
Mean & & 4.37 \\
Broad-sense heritability & $0.53(0.33-0.67)$ \\
\hline
\end{tabular}

** Statistically significant at $1 \%$ probability according to the $\mathrm{F}$ test.

act to reduce the severity of the disease in the field. Most escape mechanisms associated with white mold present high heritability and are readily evaluated in the field. Hence, the association between physiological resistance and morphological escape mechanisms constitute a viable strategy for plant improvement when the target trait is resistance to white mold (Miklas et al. 2003, Miklas et al. 2004).

It is believed that multiple variations in the estimates of heritability of white mold resistance are due to the influence of the parental genotype, the evaluation method employed and the interaction genotypes $x$ environment. For these reasons joint ANOVA was performed and the results are shown in Table 4. The effects of evaluation period on the means of the $\mathrm{F}_{2: 3}$ progenies were significant, with the largest general mean being obtained in the second evaluation. There were also significant differences between the $\mathrm{F}_{2: 3}$ progenies. However, the effects of the interaction between evaluation period $x$ progenies were not statistically significant (Table 4), indicating that the performance of the $\mathrm{F}_{2: 3}$ progenies were analogous in the two evaluations. In order to clarify the absence of interaction, the phenotypic, genetic and environmental correlations between the performance of the progenies in each evaluation period were estimated. As shown in Table 4, although the effect of the interaction between evaluation period $x$ progenies was not significant, the phenotypic and genetic correlation values were small ( 0.23 and 0.45 , respectively; $\mathrm{P} \leq 0.01)$, and the relating environmental correlation was much higher (0.60), strengthening the perception that environmental effects exerted more influence than genetic effects.

Probably, one of the factors that augmented the contribution of the environment was that the second evaluation coincided with the inflorescence period during which plants consume great quantities of energy. Thus, plants classified as resistant in the initial stages of flowering may develop symptoms of the disease afterwards. Based on the results of the joint analysis, $\hat{h}_{a}^{2}$ was estimated to be $53.5 \%$ (confidence interval 33.3-67.6\%), a value that was higher than that estimated on the basis of individual analysis.

From the results presented herein, it is possible to infer that successive inoculations increase the chances of detecting resistant populations. Indeed, Terán and Singh (2008) recommend successive evaluations in order to augment the experimental precision in the detection of different responses of the bean populations towards white mold.

\section{ACKNOWLEDGEMENTS}

The authors wish to thank Fundação de Amparo à Pesquisa do Estado de Minas Gerais (FAPEMIG) and Conselho Nacional de Desenvolvimento Científico e Tecnológico (CNPq) for financial support. 


\title{
Genética da resistência do feijoeiro ao mofo branco
}

\begin{abstract}
RESUMO - O objetivo foi estudar a natureza e a magnitude dos efeitos genéticos da resistência ao mofo branco. Para se obter as estimativas de parâmetros genéticos, foram utilizados os genitores resistente (G122) e suscetível (M20), as gerações $F_{1}, F_{2} e$ progênies $F_{2: 3}$. Foi utilizado o delineamento de blocos casualizados com duas repetições. Cada progênie foi submetida, duas vezes (repetição), à inoculação do micélio (Straw test) após, aproximadamente, 28 e 38 dias da semeadura. Seis a oito dias após a inoculação, foi realizada a avaliação em nível de planta individual e em nível de média de progênies por meio de uma escala diagramática de 1 a 9. O modelo aditivo-dominante adotado foi eficiente e no controle da resistência houve predomínio de efeito aditivo. As estimativas da herdabilidade no sentido amplo obtidas indicam que a seleção é mais eficiente com base na média de progênies e inoculações sucessivas.
\end{abstract}

Palavras-chave: Sclerotinia sclerotiorum; Phaseolus vulgaris; parâmetros genético.

\section{REFERENCES}

Abawi GS, Provvidenti R, Crosier DC and Hunter JE (1978) Inheritance of resistance to white mold disease in Phaseolus coccineus. Journal Hereditary 69: 200-202.

Antonio RP, Santos JB, Souza TP and Carneiro FF (2008) Genetic control of the resistance of common beans to white mold using the reaction to oxalic acid. Genetics and Molecular Research 7: 733-740.

Castaño F, Vear F and Tourvieille D (1993) Resistance of sunflower inbred lines to various forms of attack by Sclerotinia sclerotiorum and relations with some morphological characters. Euphytica 68: 85-98.

Chung YS, Sass ME and Nienhuis J (2008) Validation of RAPD markers for white mold resistance in two snap bean populations based on field and greenhouse evaluations. Crop Science 48: 2265-2273.

Cruz CD, Regazzi AJ and Carneiro PCS (2004) Modelos biométricos aplicados ao melhoramento genético. Editora UFV, Viçosa, 480p.

Ender M and Kelly JD (2005) Identification of QTL associated with white mold resistance in common bean. Crop Science 45: 2482-2490.

Fuller PA, Coyne DP and Steadman JR (1984) Inheritance of resistance to white mold disease in a diallel cross of dry beans. Crop Science 24: 929-933.

Hospital F (2009) Challenges for effective marker-assisted selection in plants. Genetics 136: 303-310.

Huinter JE, Abawi GS and Croiser DC (1978) Effects of timing, coverage, and spray oil control of white mold of snap bean with benomyl. Plant Disease Report 62: 633-637.

Knapp SJ, Stroup WW and Ross WM (1985) Exact confidence intervals for heritability on a progeny mean basis. Crop Science 25: 192-194.
Kelly JD, Gepts P, Miklas PN and Coyne DP (2003) Tagging and mapping of genes and QTL and molecular marker-assisted selection for traits of economic importance in bean and cowpea. Field Crops Research 82: 135.

Kolkman JM and Kelly JD (2002) Agronomic traits affecting resistance to white mold in common bean. Crop Science 42: 693-699.

Kolkman JM and Kelly (2003) QTL Conferring resistance and avoidance to white mold in common bean. Crop Science 43: 539-548.

Miklas PN, Delorme R, Johnson WC and Gepts P (2001) QTL conditioning physiological resistance and avoidance to white mold dry bean. Crop Science 41: 309-315.

Miklas PN, Delorme R and Riley R (2003) Identification of QTL conditioning resistance to white mold in snap bean. Journal American Society Horticultural Science 128: 564-570.

Miklas PN, Hauf D, Henson R and Grafton KF (2004) Inheritance of ICA Bunsi-derived resistance in a navy $\times$ pinto bean cross. Crop Science 44: 1584-1588.

Miklas PN, Kelly JD, Beebe SE and Blair MW (2006) Common bean breeding for resistance against biotic and abiotic stresses: from classical to MAS breeding. Euphytica 147: 105-131.

Park SO, Coyne DP, Steadman JR and Skroch PW (2001) Mapping of QTL for resistance to white mold disease in common bean. Crop Science 41: 1253-1262.

Petzoldt R and Dickson MH (1996) Straw test for resistance to white mold in beans. Annual Report of the Bean Improvement Cooperative 39: 142-143.

Ramalho MAP, Santos JB, Zimmermann MJO (1993) Genética quantitativa em plantas autógamas. Universidade Federal de Goiás, Goiânia, p 29-75.

Ramalho MAP, Ferreira DF and Oliveira AC (2005) Experimentação em genética e melhoramento de plantas. Universidade Federal de Lavras, Lavras, 322p. 
Genetics of common bean resistance to white mold

Schwartz HF, Otto K, Terán H, Lema M and Singh SP (2006) Inheritance of white mold resistance in Phaseolus vulgaris $\mathrm{x} P$. coccineus crosses. Plant Disease 90: 1167-1170.

Silva GS, Ramalho MAP, Abreu AFB and Silva FB (2008) Genetic control of early grain darkening of carioca common bean. Crop Breeding and Applied Biotechnology 8: 299-304.

Terán H and Singh SP (2008) Response of dry bean genotypes with different levels of resistance to Sclerotinia sclerotiorum to three inoculation methods. Annual Report of the Bean Improvement Cooperative 51: 218-219.
Vencovsky R and Barriga P (1992) Genética biométrica no fitomelhoramento. Revista Brasileira de Genética, Riberão Preto, 496p.

Wright S (1934) The results of crosses between inbred strains of guinea pigs, differing in number of digits. Genetics 19: 537 551.

Zhao J, Peltier AJ, Meng J, Osborn TC and Grau CR (2004) Evaluation of Sclerotinia stem rot resistance in oilseed Brassica napus using a petiole inoculation technique under greenhouse conditions. Plant Disease 88: 1033-1039. 